\title{
Screening of aldose reductase inhibitory activities of Korean folk plants in Chungcheong Province
}

\author{
Dong Gu Lee ${ }^{1}$, Ki Ho Lee ${ }^{1}$, Kyung Choi ${ }^{2}$, Jajung Kü ${ }^{2}$, Kwang-Woo Park ${ }^{2}$, Eun Ju Cho ${ }^{3}$, Sanghyun Lee ${ }^{1}$ * \\ ${ }^{1}$ Department of Integrative Plant Science, Chung-Ang University, Anseong 456-756, Korea \\ ${ }^{2}$ Department of Forest Resource Conservation, Korea National Arboretum, Pocheon 487-821, Korea \\ ${ }^{3}$ Department of Food Science and Nutrition, Pusan National University, Busan 609-735, Korea
}

Received on 6 December 2012, revised on 5 March 2013, accepted on 5 March 2013

\begin{abstract}
To search for the aldose reductase (AR) inhibitors from Korean folk plants, the inhibition of rat lens AR in vitro using the methanol $(\mathrm{MeOH})$ extracts from Korean folk plants in Chungcheong Province was investigated. Among Korean folk plants tested, the $\mathrm{MeOH}$ extract of Persicaria longiseta showed highest inhibition of $\mathrm{AR}$ ( $\mathrm{IC}_{50}$ value, 5.14 $\mu \mathrm{g} / \mathrm{ml}$ ). Consequently, $P$. longiseta has a possibility of new natural resources for the development of AR inhibitor for the prevention of diabetic complications.
\end{abstract}

Key words : Aldose reductase inhibition, Diabetic complications, Folk plant, Persicaria longiseta

\section{Introduction}

Folk plants are traditional plants widely known as food, disease remedy, and personal preference for a long time in people's daily life. Traditional plants are currently being investigated for various medicinal ailments, such as treatment to cure stomach ailments, bolding, headaches, and many more aspects including new and progressive viruses that are developing in the entire world (Acocks, 1975). The use of traditional medicine has been expanded globally and gaining popularity during last decade. It has been estimated that about 13,000 species of plants have been employed for at least a century as traditional medicines by various cultures around the world (Cavers, 1999). Such popularity of healthcare plant-derived products has been traced to their increasing acceptance and use in the cosmetic industry as well as to increasing public costs in the daily maintenance of personal health and well-being (Hoareau and da Silva, 1999).

\footnotetext{
*Comesponding author: Tel: +82-31-670-4688

E-mail address: slee@cau.ac.kr
}

On numerous occasions, the folklore records of many different cultures have provided leads to plants with useful medicinal properties (Balandrin et al., 1993).

Aldose reductase (AR), the enzyme that converts glucose into fructose through the polyol pathway, has been shown to play an important role in cataract formation in the lens (Kinoshita, 1990; Van Heyningen, 1959). Under hyperglycemia environment, AR is highly activated by increasing glucose contents, can cause increased accumulation of sorbitol rate by $2-4$ times (Wang et al., 2009; Ramana et al., 2001). Accumulation of sorbitol leads to abnormalities of metabolism such as osmotic swelling and oxidative stress (Kao et al., 1999; Patel et al., 2012a). And, stored sorbitol in the lens fiber is regarded as the main cause of blindness (Patel et al., 2012b) and cataract formation (Heyningen, 1959; Sugiyama et al., 2000). AR inhibitors (ARIs) can prevent or reverse early stage diabetic complications (Constantino et al., 1999; Sun et al., 2006; Drel et al., 2008; Hotta et al., 2006; Matsumoto et al., 2008). Evaluating natural sources of ARIs potential may lead to the development of safer and more effective agents against diabetic complications due to safer and more 
effective phytochemicals (Park et al., 2011; de la Fuente and Manzanaro, 2003; Kawanishi et al., 2003; Kim et al., 2010; Lee et al., 2005; Xu et al., 2010).

To search for the new natural resources of $A R$ inhibition on Korean folk plants, followed by the last report, there is a large scope for evaluations of naturally occurring ARIs from another thirty Korean folk plants. In the present paper, as a preliminary step for the evaluations of potential of naturally occurring ARIs, we tested the effects of Korean folk plants in Chungcheong Province on rat lens AR inhibition.

\section{Materials and Methods}

\section{Plant materials}

Korean folk plants in Chungcheong Province were provided by Useful Plant Resources Research Center, Korea National Arboretum, Korea (Table 1).

Table 1. Rat lens AR inhibitory activity of the $\mathrm{MeOH}$ extracts of Korean folk plants in Chungcheong Province.

\begin{tabular}{|c|c|c|}
\hline Sample & Part used & Inhibition $(\%)$ \\
\hline Acer pseudosieboldianum (Pax) Kom. & Stem \& Leaf & 15.15 \\
\hline Ampelopsis brevipedunculata (Maxim.) Trautv. & Stem \& Leaf & 54.21 \\
\hline Aralia elata (Miq.) Seem. & Leaf & 46.58 \\
\hline A. elata (Miq.) Seem. & Branch & 58.36 \\
\hline Artemisia capillaris Thunb. & Leaf \& Stem & 61.05 \\
\hline Broussonetia kazinoki Siebold & Leaf \& Branch & 46.52 \\
\hline Callicarpa japonica Thunb. & Leaf & 57.48 \\
\hline C. japonica Thunb. & Branch & 53.19 \\
\hline Clerodendrum trichotomum Thunb. & Fruit & 64.07 \\
\hline Cornus controversa Hemsl. ex Prain & Leaf & 61.07 \\
\hline C. controversa Hemsl. ex Prain & Branch & 37.60 \\
\hline Diospyros lotus L. & Leaf \& Branch & 41.92 \\
\hline Elaeagnus umbellata Thunb. & Stem \& Leaf & 18.59 \\
\hline Euonymus aponicus Thunb. & Leaf \& Branch & 14.88 \\
\hline Hoveniad ulcis Thunb. & Leaf & 29.96 \\
\hline H. ulcis Thunb. & Fruit & 3.67 \\
\hline Lactuca indica f. indivisa (Makino) Hara & Leaf \& Stem & 41.27 \\
\hline Leonurus japonicus Houtt. & Leaf & 26.91 \\
\hline Lotus corniculatus var. japonica Regel & Stem \& Leaf & 12.78 \\
\hline Melilotus suaveolens Ledeb. & Leaf \& Stem & 18.72 \\
\hline Persicaria longiseta (Bruijn) Kitagawa. & Stem \& Leaf & 86.58 \\
\hline Pinus thunbergii Parl. & Shoot & 22.11 \\
\hline P. thunbergii Parl. & Unripe fruit & 25.39 \\
\hline Portulaca oleracea L. & Whole plant & 5.00 \\
\hline Rhus javanica L. & Leaf & 66.37 \\
\hline R. javanica $\mathrm{L}$. & Branch & 45.59 \\
\hline Styrax obassia Siebold \& Zucc. & Leaf & 27.59 \\
\hline S. obassia Siebold \& Zucc. & Branch & 29.70 \\
\hline S. obassia Siebold \& Zucc. & Fruit & 1.23 \\
\hline Taxus cuspidata Siebold \& Zucc. & Stem \& Leaf & 7.53 \\
\hline
\end{tabular}




\section{Instruments and reagents}

Fluorescence was measured with a Hitachi U-3210 spectrophotometer. Solvents such as DL-glyceraldehyde, $\beta-\mathrm{NADPH}$, sodium phosphate buffer, potassium phosphate buffer, and DMSO (Sigma-Aldrich Chemical Co.) were used for rat lens AR assay.

\section{Extraction and sample preparation}

The samples were sliced and dried in an oven at 4 $5^{\circ} \mathrm{C}$ until use. Each three gram of dried, sliced Chungcheong Province, folk plant materials were extracted with methanol $(300 \mathrm{ml})$ under reflux for $3 \mathrm{~h}$. After filtration, the filtrates were concentrated in vacuo to produce methanol extracts. Each sample of $\mathrm{MeOH}$ extract $1.0 \mathrm{mg}$ was dissolved in $1 \mathrm{ml}$ DMSO solvent.

\section{Measurement of $\mathrm{AR}$ activity in vitro}

Rat lenses were removed from Sprague-Dawley male rats (weighing 250-280 g, 7 weeks) and preserved rat lenses by freezing it until use. These were homogenized and centrifuged at $10,000 \mathrm{rpm}\left(4^{\circ} \mathrm{C}, 20 \mathrm{~min}\right)$ and the supernatant was used as an enzyme source. AR activity was spectrophotometrically determined by measuring the decrease in absorption of NADPH at $340 \mathrm{~nm}$ for a $4 \mathrm{~min}$ period at room temperature with DL-glyceraldehydes as a substrate (Sato and Kador, 1990). The assay mixture contained $0.1 \mathrm{M}$ potassium phosphate buffer ( $\mathrm{pH}$ 7.0), 0.1 M sodium phosphate buffer ( $\mathrm{pH}$ 6.2), $1.6 \mathrm{mM} \mathrm{NADPH}$, and test extract sample (in DMSO) with $0.025 \mathrm{M}$ DL-glyceraldehyde as substrate in quartz cell. Each sample $(1.0 \mathrm{mg})$ of the $\mathrm{MeOH}$ extract was dissolved in DMSO (1 ml) for AR activity test. Total volume of assay mixture is $1 \mathrm{ml}$ for the test. The reaction occurred in a quartz cell. $\mathrm{IC}_{50}$ values, the concentration of inhibitors giving $50 \%$ inhibition of enzyme activity, were calculated from the least-squares regression line of the logarithmic concentrations plotted against the residual activity. 3,3-Tetramethyleneglutaric acid (TMG) known as one of typical AR inhibitors was used as a positive control.

\section{Results and Discussion}

The $\mathrm{MeOH}$ extracts of Korean folk plants in Chungcheong Province were tested for their inhibitory effects on rat lens AR, and summarized in Table 1. Among Korean folk plants tested, the $\mathrm{MeOH}$ extracts of A brevipedunculata, A elata, A capillaris, $C$ japonica, $C$ trichotomum, $C$ controversa, $P$ longiseta, and $R$ javanica were demonstrated to show good inhibitory potencies on rat lens AR. Among them, the extracts of $A$. capillaris, C. trichotomum (leaf), C. trichotomum (branch), P. longiseta, and $R$. javanica were exhibited high degree of inhibition (> 65\% at $10 \mu \mathrm{g} / \mathrm{ml}$ ) on rat lens AR compared with other samples. The extract of $P$. longiseta was particularly exhibited highest inhibitory value of $86.58 \%$ on rat lens AR. To evaluate the rat lens AR inhibitory activity, their inhibitory percentage and $\mathrm{IC}_{50}$ values were calculated. TMG known as a very strong AR inhibitor ( $\mathrm{IC}_{50}$ value, $1.49 \mu \mathrm{g} / \mathrm{ml}$ ) was used as a positive control and the results were indicated in Table 2. In particular, $P$. longiseta extract had predominant inhibitory activities with $\mathrm{IC}_{50}$ value $4.66 \mu \mathrm{g} / \mathrm{ml}$.

$P$. longiseta is a species of flowering plant in the Polygonaceae. This is annual herb produces stems 20 to $50 \mathrm{~cm}$ long, sometimes reaching one meter. The hairless, branching stems may root at lower nodes that come in contact with the substrate. Leaves are alternate, thin, and lanceolate to elliptic in shape, up to $8 \mathrm{~cm}$ long by $1-2.5$ wide. They have bristly ochrea. The inflorescence is up to $5 \mathrm{~cm}$ long and contains many pink flowers. The fruit is a small, smooth achene. Stems decumbent to ascending, branched, without noticeable ribs, glabrous. P. longiseta is native to Asia and occurs in disturbed habitats such as along roadsides and in pastures. Plants also inhabit wet areas (Lee, 1993). 
Table 2. $\mathrm{IC}_{50}$ value of the $\mathrm{MeOH}$ extract of $P$. longiseta in Chungcheong Province on rat lens AR inhibition.

\begin{tabular}{cccc}
\hline Sample & $\begin{array}{c}\text { Concentration } \\
(\mu \mathrm{g} / \mathrm{ml})\end{array}$ & $\begin{array}{c}\text { Inhibition } \\
(\%)\end{array}$ & $\begin{array}{c}\mathrm{IC}_{50}{ }^{2)} \\
(\mu \mathrm{g} / \mathrm{ml})\end{array}$ \\
\hline \multirow{2}{*}{ Persicaria longiseta } & 10 & 75.86 & 5.45 \\
& 5 & 52.66 & 1.49 \\
\hline
\end{tabular}

\footnotetext{
1) Inhibition rate was calculated as a percentage with respect to the control value.

${ }^{2)} \mathrm{IC}_{50}$ value was calculated from the least-squares regression equations in the plot of the logarithm of three graded concentrations vs \% inhibition.

* TMG was used as a positive control.
}

Consequently, $P$. longiseta was found to demonstrate good inhibitory activities on AR from in vitro data. Therefore, we suggest that $P$. longiseta in Chungcheong Province have a possibility of new natural resources for the inhibition of AR. Further investigations on the bioactivity of constituents from $P$. longiseta may prove the use of new medicinal plants for the prevention of diabetic complications.

\section{Acknowledgements}

This work was supported by grants from Scientific Research of Korea National Arboretum (KNA1-2-13, 11-5).

\section{References}

Acocks JPH. 1975. Veld types of South Africa. Memoirs of the Botanical Survey of South Africa Botanical Research Institute. p. 57. Department of Agriculture and Water Supply. Pretoria, South Africa.

Balandrin MF, Kinghorn AD, Farnsworth NR. 1993. Plant derived natural products in drug discovery and development : An overview. p. 1-10. American Chemical Society. Washington, DC, America.

Cavers PB. 1999. Canadian medicinal crops. P. 1. National research coundil of Canada. Ottawa, Canada.

Constantino L, Rastelli G, Vianello P, Cignarella G, Barlocco D. 1999. Diabetes complications and their potential prevention: aldose reductase inhibition and other approaches. Medicinal Research Reviews 19:3-23.

de la Fuente JA, Manzanaro S. 2003. Aldose reductase inhibitors from natural sources. Natural Product Reports 20:243-251. Drel VR, Pacher P, Ali TK, Shin J, Julius U, El-Remessy AB, Obrosova IG. 2008. Aldose reductase inhibitor fidarestat counteracts diabetes-associated cataract formation, retinal oxidative-nitrosative stress, glial activation, and apoptosis. International Journal of Molecular Medicine 21:667-676.

Heyningen RV. 1959. Formation of polyols by the lens of the rat with 'sugar' cataract. Nature 184:194-195.

Hoareau L, da Silva EJ. 1999. Medicinal plants: A re-emerging health aid. Electr. Journal of Biotechnolgy 2:56-70.

Hotta N, Akanuma Y, Kawamori R, Matsuoka K, Oka Y, Shichiri M, Toyata T, Nakashima M, Yoshimura I, Sakamoto N, Shigeta Y. 2006. Long-term clinical effects of epalrestat, an aldose reductase inhibitor, on diabetic peripheral neuropathy. Diabetes Care 29:1538-1544.

Kao YL, Donaghue K, Chan A, Knight J, Silink M. 1999. An aldose reductase intragenic polymorphism associated with diabetic retinopathy. Diabetes Research and Clinical Practice 46:155-160.

Kawanishi K, Ueda H, Moriyasu M. 2003. Aldose reductase inhibitors from the nature. Current Medicinal Chemistry 10:1353-1374.

Kim SH, Kim JK, Lee YS, Bae YS, Lim SS. 2010. Inhibitory effect of quercetin-3-O-a-L-rhamnopyranoside from Chamaecyparis obtuse on aldose reductase and sorbitol accumulation. Korean Journal of Medicinal Crop Science 18:305-310.

Kinoshita JH. 1990. A thirty-year journey in the polyol pathway. Experimental Eye Research 50:567-73.

Lee CB. 1993. Illustrated flora of Korea. p. 312. Hyangmunsa. Seoul, Korea.

Lee S, Shim SH, Kim JS, Shin KH, Kang SS. 2005. Aldose reductase inhibitors from the fruiting bodies of Ganoderma applanatum. Biological and Pharmaceutical Bulletin 28:11031105.

Matsumoto T, Ono Y, Kurono M, Kuromiya A, Nakamura K, Bril V. 2008. Ranirestat (AS-3201), a potent aldose reductase inhibitor, reduces sorbitol levels and improves motor nerve 
conduction velocity in streptozotocin-diabetic rats. Journal of Phamacological Science 107:231-237.

Park HY, Kwon SB, Heo NK, Chun WJ, Kim MJ, Kwon YS. 2011. Constituents of the stem of Angelica gigas with rat lens aldose reductase inhibitory activity. Journal of Korean Society of Applied Biological Science 54:194-199.

Patel DK, Kumar R, Sairam K, Hemalatha S. 2012a. Pharmacologically tested aldose reductase inhibitors isolated from plant sources-A concise report. Chinese Journal of Natural Medicine 10:388-340.

Patel DK, Prasad SK, Sairam K, Hemalatha S. 2012b. Aldose reductase inhibitory principles from the whole plant of Hybanthus enneaspermus (Linn) F. Muell. Asian Pacific Journal of Tropical Biomedicine S165-S169.

Ramana KV, Dixit BL, Srivastava S, Bhatnagar A, Balendiran GK, Watowich SJ, Petrash JM, Srivastava SK. 2001. Characterization of the glutathione binding site of aldose reductase. Chemico-Biological Interactions 130-132:537548.

Sato S, Kador PF. 1990. Inhibition of aldehyde reductase by aldose reductase inhibitors. Biochemical Pharmacology 40:1033-1042.

Sugiyama K, Chen Z, Lee YS, Kador PF. 2000. Isolation of a noncovalent aldose reductase inhibitor complex. Biochemical Pharmacology 59:329-336.

Sun W, Oates PJ, Coutcher JB, Gerhardinger C, Lorenzi M. 2006. A selective aldose reductase inhibitor of a new structural class prevents or reverses early retinal abnormalities in experimental diabetic retinopathy. Diabetes 55:2757-2762.

Van Heyningen R. 1959. Formation of polyol by the lens of the rat with sugar cataract. Nature 184:194-196.

Wang Z, Ling B, Zhang R, Suo Y, Liu Y, Yu Z, Liu C. 2009. Docking and molecular dynamics studies toward the binding of new natural phenolic marine inhibitors and aldose reductase. Journal of Molecular Graphics and Modeling 28:162-169.

Xu ML, Hu JH, Wang L, Kim HS, Jin CW, Cho DH. 2010. Antioxidant and anti-diabetes activity of extracts from Machilus thunbergii S. et Z. Korean Journal of Medicinal Crop Science 18:34-39. 